\title{
Reform of Bureau of Public Services in Framework of Prevention \& Eradication of Corruption in Indonesia
}

\section{Novita Ilmaris *) and Arpangi ${ }^{*}$}

*) Students of Master of Law, Faculty of Law, Universitas Islam Sultan Agung Semarang, E-mail: novita.ilmaris@yahoo.co.id

*) Faculty of Law, Universitas Islam Sultan Agung Semarang,

\begin{abstract}
.
Corruption in Indonesia decreases public trust, especially in the case of public services where there are still many irregularities, such as a long time, convolution and a lot of costs, so that public service bureaucracy reform is needed to realize good governance. This study aims to identify and describe the reform of the public service bureaucracy in the context of preventing and eradicating corruption in Indonesia. This study uses a normative juridical approach, which is descriptive analytical. The data used is secondary data obtained through the research library, which is then analyzed qualitatively. The result of this research is that public service bureaucratic reform in the context of preventing and eradicating corruption in Indonesia is carried out by improving the quality of public services, which aims to create equal distribution of public service quality at all levels, both at the ministry / agency level to the regional level. Bureaucratic reform in public services emphasizes the importance of improving the quality of public services, with a focus on public interests, and upholding accountability and transparency.

Keywords: Bureaucracy; Corruption; Reform; Crime.
\end{abstract}

\section{Introduction}

The Unitary State of the Republic of Indonesia is a constitutional state, thus mandated in Article 1 paragraph (3) of the 1945 Constitution of the Republic of Indonesia. The affirmation of the provisions of the Constitution of the Republic of Indonesia means that all aspects of life in society, statehood and government must always based on the law.

To realize a rule of law, one of which requires a legal instrument that is used to regulate balance and justice in all areas of life and livelihoods of the people through laws or statutory regulations. This shows that laws or regulations have an important role in the constitutional state of Indonesia. Thus, in a state of law, actions or actions carried out by both the government and its citizens without exception must be based on law. So, obeying the law is an obligation for the creation of security and order. ${ }^{1}$

One of the characteristics of a rule of law is law enforcement in society as a consequence of violations of applicable laws or regulations. The implementation and enforcement of legal norms is currently faced with the times, such as the emergence of crimes or crimes that are characterized by transnational, extraordinary crime, to transbordeless, one of which is the criminal act of

\footnotetext{
${ }^{1}$ Jawade Hafidz Arsyad dan Dian Karisma. (2018). Sentralisasi Birokrasi Pengadaan Barang \& Jasa Pemerintah, Cetakan Pertama. Jakarta: Sinar Grafika. p. 23.
} 
corruption which is included in the white collar crime. Corruption is nothing new in Indonesian society and corruption that has occurred is widespread, planned and even structured, especially the abuse of power by state officials. ${ }^{2}$

Corruption is an act that is very detrimental to the state, especially state finances which used as land for the enrichment of officials, their families and cronies. Not a small amount of the people's money that they took and the rights of people who should be able to sit in the seat of government were taken by people who did not deserve to be and did not have the ability, so that the country was destroyed. ${ }^{3}$

Lubis and Scott in his view of corruption stated that in a legal sense, corruption is behavior that benefits self-interest at the expense of others, by government officials who directly violate the legal boundaries of such behavior, whereas according to government norms it can be considered corruption if the law is violated or not in the business of such acts is reprehensible 4

In the public bureaucracy, the interests of officials are often more dominant than those of the people. As a result, various attempts to rationalize the budget system and state financial system are constantly collided with the interests of these officials, and until now the Indonesian government bureaucratic services are still less productive and far from public expectations, because of indications of corruption in them.

Government tasks carried out by bureaucrats are mostly carried out in accordance with their own thoughts and desires. Conditions that allow the creation of a bureaucratic climate and state apparatus serving the people (public servants) must continue to be pursued and optimized, because the bureaucracy of this state government still seems procedural, slow, unproductive, high cost and neglecting the public interest. ${ }^{5}$

As long as government interference (bureaucracy) is too broad in the sector of public life, it is certain that bureaucratic services will be increasingly complex (over administration) and it is possible that public activity activities will also be high-cost, especially in the economic activity sector, because experience shows that bureaucratic orientation is in the sense of red. The many tables to pass for servicing is an inefficiency in public activity. This condition is still prevalent in many government bureaucratic service sectors. This cannot be tolerated because it can contribute to public distrust of government. More broadly, investment will decrease.

\footnotetext{
${ }^{2}$ Abdul Haris, Umar Ma'ruf, dan Sri Kusriyah, Desember 2019, Role And Function Of Attorney In Order To Optimize The Prevention Of Corruption Through Establishment of TP4P/D (Case Studies In State Attorney of Grobogan), Jurnal Daulat Hukum, Vol. 2 No. 4, Fakultas Hukum Universitas Islam Sultan Agung, Semarang. p. 449.

3 Jawade Hafidz Arsyad. (2013). Korupsi Dalam Perspektif HAN (Hukum Administrasi). Jakarta: Cetakan Pertama. Sinar Grafika. p. 7.

${ }_{4}^{4}$ IGM Nurdjana. (2010), Sistem Hukum Pidana dan Bahaya Laten Korupsi "Perspektif Tegaknya Keadilan Melawan Mafia Hukum", Yogyakarta: Pustaka Pelajar. p. 16.

${ }^{5}$ Lijan Poltak Sinambela. (2008). Reformasi Pelayanan Publik, Teori, Kebijakan, dan Implementasi, Jakarta: Bumi Aksara. p. 33 and 34.
} 
To understand some of the problems that often become public complaints regarding government bureaucratic services by officials, among them can be stated: 6

- Slow down the process of completing the issuance of permits;

- Looking for various excuses, such as incomplete supporting documents, late submission of applications, and other similar excuses;

- Reasons for busy carrying out other tasks;

- Difficult to contact;

- Always slow down by using the words "in progress".

Thus, it is only natural that the accountability of the bureaucratic public is legally questionable. The public accountability of the bureaucracy is legally questionable because it has created a crisis of trust, economy, socio-culture and law as well as national integration. It is assumed that the causes of the crisis currently hitting the nation and state of Indonesia are caused by several things, one of which is the arrogance of the bureaucracy. The arrogance of the bureaucracy is also assumed to be due to the granting of enormous power to the state since the inception of the modern state. ${ }^{7}$

The Indonesian government bureaucracy has been accustomed to corrupt practices. The position and expertise of officials / bureaucrats in managing and carrying out the work of the ruler / government, especially after being given the trust of the people for that, are always considered as opportunities to exploit economic resources that benefit themselves.

The behavior pattern of the bureaucrats inherited from the colonial and feudal period that influenced the bureaucracy was that "officials positioned themselves as kings". Government bureaucratic officials are considered the center of the settlement of community affairs, the people are very dependent on these officials, not officials who depend on the people. Bureaucratic service to the people is not placed on the main consideration, but on the umpteenth considerations. ${ }^{8}$

The bureaucracy can be a source of public disappointment by the many possibilities of abuse of authority by the apparatus, corruption, and the red tape effect. If managed by irresponsible people, the bureaucracy can suppress the human rights of citizens. ${ }^{9}$

An important issue that must be improved is the government's ability and seriousness to change the mentality of the bureaucrats from the orientation of the ruler to serving the interests of society honestly and fairly, so that reform of public service bureaucracy is a necessity and very important to do.

Reform is a process of systematic, integrated and comprehensive efforts aimed at realizing good governance. Good Governance (good governance) is a system that enables effective and efficient state governance mechanisms by

\footnotetext{
${ }^{6}$ S.P. Siagian. (1996). Patologi Birokrasi, Jakarta: Bumi Aksara. p. 39.

7 Ahmad Gunaryo (Ed.). (2001) Hukum Birokrasi \& Kekuasaan di Indonesia, Semarang: Walisongo Research Institute. p. 117.

${ }^{8}$ Lijan Poltak Sinambela, op.cit. P. 54.

9 Wahyudi Kumorotomo. (2008). Etika Administrasi Negara, Jakarta: Edisi Pertama, Raja Grafindo Persada. p. 289.
} 
maintaining constructive synergy between the government, the private sector and the public. ${ }^{10}$

Carrying out reform of the public service bureaucracy will be able to restore people's trust in the government, which has so far been fading. To do this, support is needed not only from the leadership, but also from the community not to civilize corruption, so that the ideals of the Indonesian nation and state as a country free from corruption, collusion and nepotism can be achieved.

The purpose of this study is to determine and examine the reform of the public service bureaucracy in the context of preventing and eradicating criminal acts of corruption in Indonesia.

\section{Research methods}

The type of research used in writing this legal journal is normative juridical. Normative juridical research is research that is focused on examining the application of the rules or norms in positive law, ${ }^{11}$ which in this case relates to reform of the public service bureaucracy in the context of preventing and eradicating criminal acts of corruption in Indonesia. This research is descriptive analysis, because the researcher wishes to describe or explain the subject and object of the study, which then analyzes and finally draws conclusions from the results of the study. ${ }^{12}$ The data used in this research is secondary data. Secondary data is data obtained from library materials through library research, and this data is also obtained from agencies / institutions related to the purpose of this research. ${ }^{13}$ According to the data that has been obtained during the research by reading library books, then it is analyzed. The analysis used in this research is qualitative data analysis.

\section{Results and Discussion}

Corruption is one of the most common crimes committed by corruptors. This criminal act is not only committed by the government (executive), but also by individuals who are in the legislative, judiciary and private institutions. ${ }^{14}$

Corruption is a cursed act, because the bad impact it causes to a society and nation is very serious. ${ }^{15}$ Corrupt practices have an extraordinary impact that

\footnotetext{
10 Sedarmayanti. (2009) Reformasi Administrasi Publik, Reformasi Birokrasi, Dan Kepemimpinan Masa Depan (Mewujudkan Pelayanan Prima dan Kepemerintahan yang Baik), Bandung: Refika Aditama. p. 67.

11 Jhonny Ibrahim. (2011). Teori dan Metodologi Penelitian Hukum Normatif, Malang: Bayumedia. p. 295.

12 Mukti Fajar ND dan Yulianto Achmad. (2010). Dualisme Penelitian Hukum Normatif dan Empiris, Yogyakarta: Pustaka Pelajar. p. 183.

13 Soeratno dan Lincolin Arsyad. (2003). Metodologi Penelitian Untuk Ekonomi Dan Bisnis, Yogyakarta: UPP AMP YKPN. p. 173.

14 Rodliyah dan Salim HS. (2019). Hukum Pidana Khusus, Unsur dan Sanksi Pidananya, Depok: Cetakan Kedua. Raja Grafindo Persada. p. 23.

15 Endang Jumali. (2016). Rekonstruksi Sanksi Hukum Pidana Korupsi Di Indonesia, Kritik Nazhariyyah Al-Ta'zir Terhadap Undang-Undang Nomor 20 Tahun 2001 Tentang Pemberantasan Tindak Pidana Korupsi. Jakarta: Cetakan Pertama. Saadah Pustaka Mandiri. p. 2.
} 
hinders human development. There is a trade-off between corruption and governance. Countries with good governance have a tendency to incite little corruption, but on the other hand, countries with high corruption have poor governance conditions. ${ }^{16}$

Corruption is an act that can cause harm to many parties, it can even affect the existence and development of progress and the welfare of the people of a country. ${ }^{17}$ Corruption in this country, so deeply rooted and widespread that usually occurs in the central government, has now penetrated even at lower levels such as in the regions and villages. Not only in government, but also to courts, corporations, education, all aspects of life. ${ }^{18}$ Forms of corrupt practices grow and develop over time, both in quality and quantity ${ }^{19}$ and the development of corruption in Indonesia is still high, while the eradication of corruption is still very slow. ${ }^{20}$

Bearing in mind that the Unitary State of the Republic of Indonesia is a constitutional state which has the objective of making the people prosperous, as the provisions of the Fourth Paragraph of the Preamble of the 1945 Constitution of the Republic of Indonesia, that:

Then rather than that, to form an Indonesian state government that protects the entire Indonesian nation and all the blood of Indonesia and to promote public welfare, educate the nation's life, and participate in implementing world order based on independence, eternal peace and social justice, the national independence of Indonesia is compiled in a constitution of the state of Indonesia, which is formed in a state structure of the Republic of Indonesia which is sovereignty of the people.

Thus, the criminal act of corruption can hinder government or state programs for the welfare of its people as the ideals of the Unitary State of the Republic of Indonesia listed in the Fourth Paragraph of the Preamble of the 1945 Constitution of the Republic of Indonesia. From the objectives of the state as stated in the fourth paragraph of the preamble to the 1945 Constitution of the Republic of Indonesia, it can be identified that Indonesia is a law state that adheres to the concept of a welfare state.

The understanding of a rule of law cannot be separated from popular understanding. Laws that regulate and limit state power (government) are defined as laws made on the basis of people's power or sovereignty. In relation to the rule

\footnotetext{
16 Imam Anshori Saleh. (2017). Korupsi, Terorisme, dan Narkoba, Upaya Melawan Kejahatan Luar Biasa yang Sistematis. Malang: Cetakan Pertama. Setara Press. p. 3.

17 Hulman Siregar, March (2018). Rumusan Pidana dan Pemidanaan Tindak pidana Korupsi Yang Merugikan Keuangan Negara Serta Permasalaan Dalam Penerapannya, Jurnal Daulat Hukum, Vol. 1. No. 1, Fakultas Hukum UNISSULA, Semarang, p. 126.

18 Luk Har Syan'in, Gunarto, dan Widayati, March (2019). Criminal Investigation Polres Kudus Unit Efforts In The Prevention Of The Corruption In Village Funds Management, Jurnal Daulat Hukum, Vol. 2 No. 1, Fakultas Hukum UNISSULA, Semarang, p. 69.

19 Hulman Siregar dan Rakhmat Bowo Suharto, September (2018). Analysis and Review of The Implementation of Law Enforcement Operations Juridical Capture Corruption in The Criminal Justice System, Jurnal Daulat Hukum, Vol. 1 No. 3, Fakultas Hukum UNISSULA, Semarang, p. 844.

20 Muhamad Riyadi Putra dan Gunarto, Juni (2019). Analysis Of Handling Practices On Corruption Crime By Police (Case Study In Special Criminal Investigation Police Directorate Of Central Java), Jurnal Daulat Hukum, Vol. 2 No. 2, Fakultas Hukum UNISSULA, Semarang, p. 209.
} 
of law, people's sovereignty is a material element of the rule of law, in addition to the issue of people's welfare. ${ }^{21}$

As a rule of law that aims to create general welfare, every activity carried out must be oriented towards the goals to be achieved and based on applicable law as a rule of state, government and social activities.

The state must be able to provide various means and necessities of life for its people as the implementation of the understanding of the welfare state, so that the state is required to play a further role and intervene in every aspect of people's lives in the context of realizing prosperity, by carrying out development evenly at the national level and region.

The administration of public services is one of the efforts of the government for the realization of people's welfare. In other words, public service is one of the concepts to achieve what the people and the state want.

Public services according to Article 1 number 1 of Act No. 25 of 2009 concerning Public Services are: "Activities or a series of activities in order to fulfill service needs in accordance with statutory regulations for every citizen and resident of goods, services, and / or administrative services provided by public service providers".

The government carries out development in all fields, including political, social, economic, cultural, as well as defense and security. In this national development, the government must also do its best to meet the needs of society for public services.

Providing services to the community is a major obligation for the government. The role of government in the service delivery process is to act as a catalyst that accelerates the process according to what it should be. By playing the service as a catalyst, of course, it will become the foundation of government organizations in providing the best service to the community. Public service in its development arises from an obligation as a process of organizing government activities, both individually and in groups. ${ }^{22}$

The thing that must be emphasized is the status of the public servant (public service) of the government bureaucracy, which is tasked with providing the best service for the people, not for themselves or their groups. If you can be sure that the laws and regulations that underlie the work / service system of the government bureaucracy are oriented towards the interests of the people and are socially just, and are carried out in a non-discriminatory, transparent, objective and firm manner, then gradually the community will follow this pattern.$^{23}$

Quality public service (public service) is a measure to assess a good governance (good governance), while bad public service reflects a government that

\footnotetext{
21 Juniarso Ridwan dan Achmad Sodik Sudrajat. (2014). Hukum Administrasi Negara dan Kebijakan Pelayanan Publik. Bandung: Cetakan Keempat. Nuansa Cendekia. p. 11.

22 Adrian Sutedi. (2015). Hukum Perizinan Dalam Sektor Pelayanan Publik. Jakarta: Edisi Kesatu. Cetakan Ketiga. Sinar Grafika. p. 3.

23 Didin S. Damanhuri. (2006). Korupsi, Reformasi Birokrasi dan Masa Depan Ekonomi Indonesia. Jakarta: Lembaga Penerbit Fakultas Ekonomi Universitas Indonesia. p. 13.
} 
is poor in innovation and does not have the desire to improve the welfare of its people (bad governance). ${ }^{24}$

The problem of professionalism, effectiveness and efficiency in providing public services is something that is absolutely necessary. As the Prophet Muhammad SAW said that: "Make it easy (in matters) and do not make it difficult, preach good news and do not make people run, agree and do not dispute".

Public service from the government bureaucracy is to provide the best service for the people, not for officials, families, or groups. The government bureaucracy must be oriented towards the interests of the people and social justice, which should be carried out in a non-discretionary, transparent, objective and firm manner.

The government must prioritize the interests of its people, but what happens is the opposite. State officials, bureaucrats and even civil servants are competing to seek profit by taking advantage of their position or power. The interests and needs of the people are ignored, even though the people only ask the government to give them their rights, one of which is by providing good public services.

The most fundamental problem faced by the government of the Republic of Indonesia after the economic crisis is the decline in public trust in the public bureaucracy and the government system, because so far the bureaucracy has only been used as a political tool by the ruling regime. Now, the people find it difficult to appreciate what government officials, bureaucrats, or other elements in the public bureaucracy are doing. ${ }^{25}$

Society at any time will always demand quality public services from bureaucrats, even though these demands are often not in accordance with what is expected, because empirically the public services that have occurred so far still display characteristics, namely convoluted, slow, expensive, and tiring. . This tendency occurs because the community is still positioned as the party that "serves" not the "served". 26

In the eyes of the public, bureaucracy is synonymous with corruption, inefficiency, convoluted services, low levels of accountability, responsiveness, and efficiency in the delivery of public services. The pros and cons of public services provided by the bureaucracy are closely related to the capability and quality of the bureaucracy itself. ${ }^{27}$

The bureaucracy in Indonesia cannot be said to be good, in fact it is far from good. Indonesian government bureaucratic services, both central and regional, are still less productive and far from public expectations. This makes people reluctant

\footnotetext{
24 Utang Rosidin. (2010). Otonomi Daerah dan Desentralisasi. Bandung: Cetakan Kesatu. Pustaka Setia. p. 188.

25 Wahyudi Kumorotomo. (2008). Akuntabilitas Birokrasi Publik, Sketsa Pada Masa Transisi. Yogyakarta: Magister Administrasi Publik (MAP) dan Pustaka Pelajar. p. 3.

26 Juniarso Ridwan dan Achmad Sodik Sudrajat. (2009). Hukum Administrasi Negara dan Kebijakan Pelayanan Publik. Bandung: Nuansa. p. 17.

27 Fahmi, D.B. Paranoan, dan Enos Paselle. (2013). Evaluasi Kebijakan Bupati Kukar Nomor 6 Tahun 2011 Tentang Pelimpahan Sebagian Kewenangan Bupati Kepada Camat (Studi Kasus Kecamatan Samboja), eJournal Administrative Reform, Vol. 1 No. 2, Program Magister Ilmu Administrasi Negara Fisip UNMUL, Samarinda. p. 459.
} 
if they have to deal with government bureaucracy, although like it or not they have to deal with bureaucracy from birth to the end of their lives.

It is impossible for public services (general) to be carried out without the existence of bureaucracy. However, the bureaucracy can be a source of disappointment for the community by the many possibilities of abuse of authority by the apparatus and corruption. If managed by people who are not qualified and people who are not responsible, the bureaucracy can suppress the human rights of citizens. ${ }^{28}$

The government bureaucracy has at least 3 (three) main tasks, namely: 29

- Providing routine public services to the community, such as providing licensing services, making documents, protecting, maintaining public facilities, maintaining health, and providing security guarantees for the population;

- Conducting empowerment (empowerment) for the community to achieve progress in a better life, such as providing guidance, mentoring, consultation, providing capital and business facilities, and implementing education;

- Carrying out development (development) in the community, such as building transportation infrastructure, telecommunications, trade, and so on.

The convoluted public service bureaucracy is full of corruption, the length of time to get services, the number of agencies that issue licenses, and the large number of fees that must be paid is one of the problems that hinders economic development, so it is very necessary to carry out bureaucratic reform of public services in Indonesia.

In the amendments to the 1945 Constitution, bureaucratic reform is interpreted as a rearrangement of the governance system run by government officials, both at the local and national government levels.

Bureaucratic reform is essentially aimed at the implementation of a bureaucratic system that is effective, clean, competitive, and responsive to changes and pro-people. Bureaucratic reform is needed because it is for saving the state budget, optimizing resource allocation, optimizing performance, improving service quality, preventing corruption, and improving the system.

Bureaucratic reform in the context of preventing and eradicating corruption, in this case because the government bureaucracy is more susceptible to corruption, namely inefficiency in the use of the state budget is not completely addressed. Corruption eradication must touch the bureaucrats and provide reliable instruments to prevent corruption.

Bureaucratic reform cannot be ruled out and it is time for the people and economic actors in Indonesia to take part in pushing for bureaucratic reform. The habit of giving collateral in the form of bribes, cigarette money, and others has led to systemic damage and exacerbated the increasingly critical condition of the bureaucratic pathology.

One of the implementation of bureaucratic reform is to realize good governance, ontologically a change in the paradigm of government towards governance is manifested in a shift in mindset and orientation of the bureaucracy

\footnotetext{
28 Wahyudi Kumorotomo. (2008). Etika Administrasi..., loc.cit. p. 289.

29 Budi Setiyono. (2004). Birokrasi Dalam Perspektif Politik dan Administrasi. Semarang: Puskodak Undip. p. 87.
} 
that originally served the interests of power to improve the quality of public services. ${ }^{30}$

Bureaucratic reform is predicted to make fundamental changes to the government administration system. The goal is of course to achieve good governance, otherwise known as good governance.

The government continues to echo the spirit of change in the framework of bureaucratic reform. Presidential Regulation Number 81 of 2010 concerning the Grand Design of Bureaucratic Reform 2010-2025, as stipulated in Article 2 that the 2010-2025 Bureaucratic Reform Grand Design is a reference for Ministries / Institutions / Regional Governments in carrying out bureaucratic reform in order to realize good governance.

In the reform of the public service bureaucracy, what needs to be improved is the quality of public services, which aims to create equal distribution of the quality of public services at all levels, both at the ministry / agency level to the regional level. Increasing the quality of public services must be in accordance with the needs and expectations of the community. Because there are 3 (three) targets in the Regulation of the Minister for Administrative Reform and Bureaucratic Reform Number 26 of 2020 concerning Guidelines for Evaluating the Implementation of Bureaucratic Reform, namely:

- Realizing public services (faster, cheaper, safer, and easier to reach);

- Increasing the number of service units that obtain service standardization; and

- Increased index of public satisfaction with the implementation of public services by each operator at all levels, both ministries / agencies, to local governments.

Bureaucratic reform in public services emphasizes the importance of improving the quality of public services, with a focus on the interests of the community, and upholding accountability and transparency. Bureaucratic reform in public services emphasizes that basically the bureaucracy must be ready to be assessed and conveyed to the public.

The community has the right to provide input, correction and improvement to services. This is what is called modern public management (new public management), which has the characteristic that the authority rests with service officers and customers; emphasizing service that "touches the heart" and reforming the vision and mission of the ministry. Furthermore, the concept has developed into a modern public service (new public service) which has the characteristic that the community is considered to be a shareholder, so that the service places more emphasis on quality as a result of negotiations on the interests of the community and government. ${ }^{31}$

The development of studies in management science, in the development of human resource management (HRM), especially in the bureaucratic management sector, is directed at the concept of "the new public service" put forward by JV

\footnotetext{
30 Sedarmayanti. op.cit. p. 114 and 115.

31 Sad Dian Utomo (Ed.), Agustus (2010). Kebijakan Pelayanan Administrasi Terpadu Kecamatan (PATEN), Inovasi Manajemen Pelayanan Di Kecamatan. Jakarta: Direktorat Jenderal Pemerintahan Umum Kementerian Dalam Negeri Republik Indonesia dan Australia Indonesia Partnership. p. 28.
} 
Denhardt and RB Denhart which states that the current demands for state apparatus are: ${ }^{32}$

- Serve citizen not customers (serve citizen not customers);

- Prioritizing the public interest (seek the public interest);

- Value citizenship over entrepreneurship;

- Have a vision and strategic mission and act democracy (think strategically, act democratilly);

- Realizing that accountability is not something easy (recognize that accountability is not simple);

- Serving rather than controlling or controlling (serve rather than steer); and

- Respect for people, not just productivity (value people, not just productivity).

HAS Moenir stated that bureaucrats must actually provide their best services to the community, because as parties who want to get good and satisfying service, the manifestations of these coveted services are: 33

- Ease in managing interests with fast service in the sense that without obstacles that are sometimes made up;

- Obtain a reasonable service. That is, services provided without using words that lead to a request for something, either for reasons of service or reasons for welfare;

- Get the same treatment in service for the same interests, orderly, and indiscriminately. This means, if indeed to arrange an application, you must queue in an orderly manner, all of them should also be required to queue, and anyone who does not go through the queue will not be served;

- Honest and frank service. This means that if there is an obstacle due to an inevitable problem, it should be informed, so that people do not wait for something uncertain. With notification, people can understand and will conform sincerely without emotion. Basically, everyone can understand the difficulties or problems of others, if they are put forward candidly. If the real problem is often hidden, it will cause disappointment in people who feel they have not been given an honest explanation. The emergence of disappointment is an "advertisement" that is very detrimental, especially for businesses engaged in services and do not have monopoly rights.

Meier argues that the government bureaucratic model that is relevant to the demands of society is "good governance", which is essentially a way of managing government that allows efficient public services, reliable control systems, and administrators are accountable to the public. The problem of efficiency in Islam has been explained in the Qur'an in QS Israa 'verses 26-27: "... Do not waste your wealth lavishly. In fact, the extravagant is a brother of Satan and the devil has really denied the Lord ".34

\footnotetext{
32 Ridwan HR. (2006). Hukum Administrasi Negara, Edisi Pertama. Jakarta: Cetakan Kesatu. Raja Grafindo Persada. p. 69 and 70.

33 H.A.S Moenir. (2001). Manajemen Pelayanan Umum Di Indonesia, Bumi Aksara, Jakarta: p. 41-44.

34 Muhammadiah. (2012). Islam dan Good Governance : Perspektif Hak Asasi Untuk Pelayanan Publik, Al-Fikr, Vol. 16. No. 2, Fakultas Sospol Universitas Muhammadiyah Makassar, Makassar, p. 10.
} 
Good governance want an efficient government for society. The interests of the community take precedence, because basically the task of the government is to improve the welfare of its people.

The existence of good governance is the recognition of human existence through empowerment and efficient service provision for various needs. Good governance is a government system oriented towards public service, namely customer satisfaction. A good governance system of governance, in which the community is the strategic stakeholder, should get the maximum benefits. ${ }^{35}$

For the public service bureaucracy in Indonesia, it is very necessary to implement the principles of good governance as stated in Article 3 of Act No. 28 of 1999 concerning State Administrators who are Clean and Free from Corruption, Collusion and Nepotism. In addition, the aim of public service to the community is to satisfy the community, so that to achieve that satisfaction, excellent service quality is required, such as transparency, accountability, conditionality, participation, equality of rights, and balance of rights and obligations. Thus, good public service to the community can be realized.

\section{Closing}

Reform of the public service bureaucracy in the context of preventing and eradicating corruption in Indonesia implemented by improving the quality of public services, which aims to achieve equal distribution of quality of public services at all levels, both at the ministry / agency level to the regional level. Increasing the quality of public services must be in accordance with the needs and expectations of the community. Bureaucratic reform in public services emphasizes the importance of improving the quality of public services, with a focus on public interests, and upholding accountability and transparency. Bureaucratic reform in public services emphasizes that basically the bureaucracy must be ready to be assessed and conveyed to the public. One of the implementation of bureaucratic reform is to create good governance, which requires efficient governance for society.

It is necessary to implement a reward and punishment system for bureaucrats and government agencies that provide the best public services, and the public can provide an assessment of the quality of these public services.

\section{References}

\section{Journals:}

[1] Abdul Haris, Umar Ma'ruf, dan Sri Kusriyah, Desember 2019, Role And Function Of Attorney In Order To Optimize The Prevention Of Corruption Through Establishment of TP4P/D (Case Studies In State Attorney of Grobogan), Jurnal Daulat Hukum, Vol. 2 No. 4, Fakultas Hukum Universitas Islam Sultan Agung, Semarang.

[2] Endang Jumali, 2016, Rekonstruksi Sanksi Hukum Pidana Korupsi Di Indonesia, Kritik Nazhariyyah Al-Ta'zir Terhadap Undang-Undang Nomor 20 Tahun 2001

35 Ibid., p. 2. 
Tentang Pemberantasan Tindak Pidana Korupsi, Cetakan Pertama, Saadah Pustaka Mandiri, Jakarta.

[3] Fahmi, D.B. Paranoan, dan Enos Paselle, 2013, Evaluasi Kebijakan Bupati Kukar Nomor 6 Tahun 2011 Tentang Pelimpahan Sebagian Kewenangan Bupati Kepada Camat (Studi Kasus Kecamatan Samboja), eJournal Administrative Reform, Vol. 1 No. 2, Program Magister Ilmu Administrasi Negara Fisip UNMUL, Samarinda.

[4] Hulman Siregar dan Rakhmat Bowo Suharto, September 2018, Analysis and Review of The Implementation of Law Enforcement Operations Juridical Capture Corruption in The Criminal Justice System, Jurnal Daulat Hukum, Vol. 1 No. 3, Fakultas Hukum UNISSULA, Semarang.

[5] Hulman Siregar, March 2018, Rumusan Pidana dan Pemidanaan Tindak pidana Korupsi Yang Merugikan Keuangan Negara Serta Permasalahan Dalam Penerapannya, Jurnal Daulat Hukum, Vol. 1. No. 1, Fakultas Hukum UNISSULA, Semarang.

[6] Luk Har Syan'in, Gunarto, dan Widayati, March 2019, Criminal Investigation Polres Kudus Unit Efforts In The Prevention Of The Corruption In Village Funds Management, Jurnal Daulat Hukum, Vol. 2 No. 1, Fakultas Hukum UNISSULA, Semarang.

[7] Muhamad Riyadi Putra dan Gunarto, Juni 2019, Analysis Of Handling Practices On Corruption Crime By Police (Case Study In Special Criminal Investigation Police Directorate Of Central Java), Jurnal Daulat Hukum, Vol. 2 No. 2, Fakultas Hukum UNISSULA, Semarang.

[8] Muhammadiah, 2012, Islam dan Good Governance: Perspektif Hak Asasi Untuk Pelayanan Publik, Al-Fikr, Vol. 16. No. 2, Fakultas Sospol Universitas Muhammadiyah Makassar, Makassar.

\section{Books:}

[1] Adrian Sutedi. (2015). Hukum Perizinan Dalam Sektor Pelayanan Publik. Jakarta: Edisi Kesatu. Cetakan Ketiga. Sinar Grafika.

[2] Ahmad Gunaryo (Ed.). (2001). Hukum Birokrasi \& Kekuasaan di Indonesia. Semarang: Walisongo Research Institute.

[3] Budi Setiyono. (2004). Birokrasi Dalam Perspektif Politik dan Administrasi. Semarang: Puskodak Undip.

[4] Didin S. Damanhuri. (2006). Korupsi, Reformasi Birokrasi dan Masa Depan Ekonomi Indonesia. Jakarta: Lembaga Penerbit Fakultas Ekonomi Universitas Indonesia.

[5] H.A.S Moenir. (2001). Manajemen Pelayanan Umum Di Indonesia. Jakarta: Bumi Aksara.

[6] IGM Nurdjana. (2010). Sistem Hukum Pidana dan Bahaya Laten Korupsi "Perspektif Tegaknya Keadilan Melawan Mafia Hukum". Yogyakarta: Pustaka Pelajar.

[7] Imam Anshori Saleh. (2017). Korupsi, Terorisme, dan Narkoba, Upaya Melawan Kejahatan Luar Biasa yang Sistematis. Malang: Cetakan Pertama, Setara Press. 
[8] Jawade Hafidz Arsyad dan Dian Karisma. (2018). Sentralisasi Birokrasi Pengadaan Barang \& Jasa Pemerintah. Jakarta: Cetakan Pertama. Sinar Grafika.

[9] Jawade Hafidz Arsyad, (2013). Korupsi Dalam Perspektif HAN (Hukum Administrasi). Jakarta: Cetakan Pertama. Sinar Grafika.

[10] Jhonny Ibrahim. (2011). Teori dan Metodologi Penelitian Hukum Normatif. Malang: Bayumedia.

[11] Juniarso Ridwan dan Achmad Sodik Sudrajat. (2009). Hukum Administrasi Negara dan Kebijakan Pelayanan Publik. Bandung: Nuansa.

[12] Juniarso Ridwan dan Achmad Sodik Sudrajat. (2014). Hukum Administrasi Negara dan Kebijakan Pelayanan Publik. Bandung: Cetakan Keempat, Nuansa Cendekia.

[13] Lijan Poltak Sinambela. (2008). Reformasi Pelayanan Publik, Teori, Kebijak-an, dan Implementasi. Jakarta: Bumi Aksara.

[14] Mukti Fajar ND dan Yulianto Achmad. (2010). Dualisme Penelitian Hukum Normatif dan Empiris. Yogyakarta: Pustaka Pelajar.

[15] Ridwan HR. (2006). Hukum Administrasi Negara. Jakarta: Edisi Pertama. Cetakan Kesatu, Raja Grafindo Persada.

[16] Rodliyah dan Salim HS. (2019). Hukum Pidana Khusus, Unsur dan Sanksi Pidananya. Depok: Cetakan Kedua, Raja Grafindo Persada.

[17] S.P. Siagian. (1996). Patologi Birokrasi. Jakarta: Bumi Aksara.

[18] Sad Dian Utomo (Ed.), Agustus (2010). Kebijakan Pelayanan Administrasi Terpadu Kecamatan (PATEN), Inovasi Manajemen Pelayanan Di Kecamatan. Jakarta: Direktorat Jenderal Pemerintahan Umum Kementerian Dalam Negeri Republik Indonesia dan Australia Indonesia Partner-ship.

[19] Sedarmayanti. (2009). Reformasi Administrasi Publik, Reformasi Birokrasi, Dan Kepemimpinan Masa Depan (Mewujudkan Pelayanan Prima dan Kepemerintahan yang Baik). Bandung: Refika Aditama.

[20] Soeratno dan Lincolin Arsyad. (2003). Metodologi Penelitian Untuk Ekonomi Dan Bisnis. Yogyakarta: UPP AMP YKPN.

[21] Utang Rosidin. (2010). Otonomi Daerah dan Desentralisasi. Bandung: Cetakan Kesatu. Pustaka Setia.

[22] Wahyudi Kumorotomo. (2008). Akuntabilitas Birokrasi Publik, Sketsa Pada Masa Transisi. Yogyakarta: Magister Administrasi Publik (MAP) dan Pustaka Pelajar.

[23] Wahyudi Kumorotomo. (2008). Etika Administrasi Negara. Jakarta: Edisi Pertama. Raja Grafindo Persada. 